\title{
PENGARUH PENGGUNAAN KONSENTRAT DALAM PAKAN BERBASIS RUMPUT (Panicum maximum) TERHADAP KECERNAAN HEMISELULOSA DAN SELULOSA PADA KAMBING LOKAL
}

\author{
Rizky S. Ramadhan*, K. Maaruf**, B. Tulung**, M. R. Waani** \\ Fakultas Peternakan, Universitas Sam Ratulangi, Manado
}

\begin{abstract}
ABSTRAK
Penelitian ini dilakukan untuk mengetahui seberapa besar pengaruh penggunaan konsentrat dalam pakan berbasis rumput benggala terhadap kecernaan hemiselulosa dan selulosa pada kambing lokal. Penelitian ini menggunakan 12 ekor kambing jantan lokal dan ditempatkan dalam 12 unit kandang individu. Rancangan penelitian yang digunakan yaitu Rancangan Acak Lengkap (RAL), terdiri dari 4 perlakuan dan 3 ulangan. Perlakuan terdiri dari R1 $=100 \%$ rumput benggala, $\mathrm{R} 2=75 \%$ rumput benggala $+25 \%$ konsentrat, R3 $=50 \%$ rumput benggala $+50 \%$ konsentrat, dan R4 $=25 \%$ rumput benggala $+75 \%$ konsentrat. Variabel yang diamati yaitu kecernaan hemiselulosa dan kecernaan selulosa. Hasil analisis keragaman menunjukkan bahwa perlakuan memberikan pengaruh nyata $(\mathrm{P}<0,05)$ terhadap kecernaan hemiselulosa dan kecernaan selulosa. Uji Beda Nyata Jujur (BNJ) menunjukkan bahwa perlakuan R1 nyata lebih rendah dibanding perlakuan R3 dan R4. Perlakuan R1 tidak

berbeda nyata dengan R2. Tidak ada perbedaan nyata antara $\mathrm{R} 1$ dan $\mathrm{R} 2$, dan juga

antara R2, R3, dan R4. Berdasarkan hasil tersebut, dapat disimpulkan bahwa penggunaan konsentrat dapat mencapai 75

$\%$, tetapi yang terbaik adalah pada penggunaan $25 \%$ konsentrat.
\end{abstract}

*Alumni Fakultas Peternakan Unsrat

**Jurusan Nutrisi dan Makanan Ternak

\author{
Kata Kunc : rumput benggala, \\ konsentrat, kecernaan, \\ hemiselulosa, selulosa, \\ kambing lokal
}

\begin{abstract}
THE EFFECT OF CONCENTRATE UTILIZATION IN GUINEA GRASS (Panicum maximum) FEED ON HEMIELLULOSE AND CELLULOSE DIGESTIBILITIES IN LOCAL GOATS. Research was conducted to evaluate the effects of concentrate utilization in guinea grass (Panicum maximum) feed on hemicellulose and cellulose digestibilities in local goats. Twelve male local goats were used in this experiment and raised in 12 unit individual pens. Completely
\end{abstract} Randomized Design (CRD) with four treatments and three replications was used. The treatments were R $1=100 \%$ guinea grass, $\mathrm{R} 2=75 \%$ guinea grass + $25 \%$ concentrate, $\mathrm{R} 3=50 \%$ guinea grass $+50 \%$ concentrate, R4 $=25 \%$ guinea grass $+75 \%$ concentrate. The results showed that effects on hemicellulose and cellulose digestibilities were significantly different among treatments $(\mathrm{P}<0,05)$. Honestly Significant Difference (HSD) showed that R1 treatment was significantly lower compared to R3 and R4 treatments. There was no different between R1 and R2, and among R2, R3, and R4. It was concluded that concentrate could be utilized up to $75 \%$, however the best treatment was utilization of $25 \%$ concentrate. 
Key words: guinea grass, concentrate, digestibility, hemicellulose, cellulose, and local goats.

\section{PENDAHULUAN}

Ternak ruminansia memanfaatkan hijauan sebagai pakan utama. Hijauan merupakan sumber utama serat kasar yang dibutuhkan ternak ruminansia agar proses pencernaan berlangsung secara normal (Siregar, 1994). Rumput benggala (Panicum maximum) merupakan salah satu hijauan yang dimanfaatkan sebagai pakan tunggal pada ternak kambing. Hartadi dkk. (1980) melaporkan bahwa rumput benggala mengandung bahan kering $20 \%$, abu 3,1 \%, lemak kasar $0,5 \%$, serat kasar 6,1\%, dan protein kasar 2,6\%.

Untuk ternak yang berproduksi tinggi, dibutuhkan penambahan konsentrat. Konsentrat merupakan bahan pakan atau campuran beberapa bahan pakan baik yang berasal dari nabati maupun hewani yang mengandung zat-zat makanan seperti protein, karbohidrat, lemak, dan serat kasar (Katipana dkk., 1994). Konsentrat mengandung serat kasar kurang dari $18 \%$ (Tillman dkk. 1989). Rendahnya kandungan serat kasar membuat konsentrat mudah dicerna.

Pakan dengan kandungan protein yang tinggi akan meningkatkan pertumbuhan dan aktivitas mikroba rumen. McDonald dkk. (1995) menyatakan bahwa apabila kandungan protein dalam pakan rendah, maka konsentrasi amonia rumen akan rendah dan pertumbuhan mikroba rumen menjadi lambat dan mengakibatkan terhambatnya degradasi karbohidrat. Hemiselulosa dan selulosa merupakan komponen dari dinding sel tanaman yang tingkat kecernaannya tergantung dari populasi dan aktivitas mikroba rumen.

Owen dan Goetsch (1988) menyatakan bahwa pada $\mathrm{pH} 5,5$ 6,2 aktivitas bakteri selulolitik dan hemiselulolitik akan terhambat dan meningkatkan aktivitas bakteri amilolitik sehingga kecernaan serat menurun. Hal ini terjadi pada ternak yang mendapat suplementasi konsentrat yang mengandung tinggi karbohidrat non struktural. Sebaliknya, pada pH 6,2 - 7,0 aktivitas bakteri selulolitik dan hemiselulolitik akan meningkat dan 
lebih dominan dibanding aktivitas bakteri amilolitik sehingga kecernaan serat meningkat. Hal ini terjadi pada saat ternak lebih banyak mengkonsumsi pakan berserat.

$$
\text { Berdasarkan pemikiran }
$$

tersebut, maka telah dilakukan suatu penelitian yang mengkaji seberapa besar pengaruh penggunaan konsentrat dalam pakan berbasis rumput benggala terhadap kecernaan hemiselulosa dan selulosa pada kambing lokal.

\section{MATERI DAN METODE PENELITIAN \\ Penelitian ini telah \\ dilaksanakan di kandang dan laboratorium Nutrisi dan Makanan Ternak Fakultas Peternakan Universitas Sam Ratulangi Manado sejak bulan September sampai dengan November 2013. Ternak yang digunakan dalam penelitian ini adalah kambing lokal berjenis kelamin jantan sebanyak 12 ekor}

dengan kisaran berat badan 11 - 17 kilogram. Model kandang yang digunakan adalah kandang individu yang terbuat dari balok dan bambu dengan panjang $110 \mathrm{~cm}$ x lebar 60 $\mathrm{cm} x$ tinggi $80 \mathrm{~cm}$. Setiap unit kandang dilengkapi tempat pakan, tempat minum, dan penampung feses. Peralatan yang digunakan yaitu timbangan digital untuk menimbang pakan, dan timbangan merk passport berkapasitas $50 \mathrm{~kg}$ dengan tingkat ketelitian 100 gram untuk menimbang ternak. Pakan yang digunakan adalah rumput benggala dan konsentrat yang terdiri dari campuran jagung, dedak halus, bungkil kelapa, dan tepung ikan. Tabel 1 menampilkan formulasi pakan konsentrat, Tabel 2 menampilkan komposisi zat-zat makanan bahan-bahan pakan penelitian, Tabel 3 menampilkan formulasi pakan dan komposisi zatzat makanannya.

\section{Tabel 1. Formulasi pakan konsentrat (dasar bahan kering)}

\begin{tabular}{lc}
\hline Bahan Pakan & Penggunaan (\%) \\
\hline Jagung & 50 \\
Dedak halus & 20 \\
Bungkil kelapa & 20 \\
Tepung ikan & 10 \\
\hline Total & 100 \\
\hline
\end{tabular}


Tabel 2. Komposisi zat-zat makanan bahan pakan penelitian (dasar bahan kering)

\begin{tabular}{lcc}
\hline \multirow{2}{*}{ Zat-zat makanan $(\%)$} & \multicolumn{2}{c}{ Bahan pakan } \\
\cline { 2 - 3 } & Rumput benggala & Konsentrat \\
\hline Bahan kering & 21.00 & 90.00 \\
Bahan organik & 87.65 & 93.65 \\
Protein kasar & 13.00 & 20.37 \\
ADF & 44.01 & 18.78 \\
NDF & 64.94 & 38.05 \\
Selulosa & 35.81 & 11.97 \\
Hemiselulosa & 20.98 & 19.27 \\
Lignin & 14.33 & 4.90 \\
\hline
\end{tabular}

Ket. : Hasil Analisa Laboratorium Nutrisi dan Makanan Ternak Fakultas Peternakan, Universitas Sam Ratulangi (2013)

Tabel 3. Formulasi pakan dan komposisi zat-zat makanannya (dasar bahan kering)

\begin{tabular}{lrrrr}
\hline \multirow{2}{*}{ Bahan pakan } & \multicolumn{4}{c}{ Perlakuan } \\
\cline { 2 - 5 } & $\mathrm{R} 1(\%)$ & $\mathrm{R} 2(\%)$ & $\mathrm{R} 3(\%)$ & $\mathrm{R} 4(\%)$ \\
\hline Rumput benggala & 100 & 75 & 50 & 25 \\
Konsentrat & 0 & 25 & 50 & 75 \\
\hline Total & 100 & 100 & 100 & 100 \\
\hline Komposisi zat makanan (\%) & & & & \\
\hline Bahan organik & 87.65 & 89.15 & 90.65 & 92.15 \\
Protein kasar & 13.00 & 14.84 & 16.68 & 18.52 \\
ADF & 44.01 & 37.70 & 31.39 & 25.09 \\
NDF & 64.94 & 58.22 & 51.50 & 44.77 \\
Lignin & 14.33 & 11.97 & 9.62 & 7.26 \\
Hemiselulosa & 20.98 & 20.55 & 20.13 & 19.70 \\
Selulosa & 35.81 & 29.85 & 23.89 & 17.93 \\
\hline
\end{tabular}

Penelitian ini menggunakan rancangan acak lengkap (RAL) menurut petunjuk Steel dan Torrie (1993), terdiri dari 4 perlakuan dan 3 ulangan. Perlakuan yang diterapkan terdiri dari $\mathrm{R} 1=100 \%$ rumput benggala, $\mathrm{R} 2=75 \%$ rumput benggala $+25 \%$ konsentrat, $\mathrm{R} 3=50$ $\%$ rumput benggala $+50 \%$ konsentrat, $\mathrm{R} 4=25 \%$ rumput benggala $+75 \%$ konsentrat. Variabel yang diamati yaitu kecernaan hemiselulosa dan kecernaan selulosa dengan menggunakan rumus :

1. Kecernaan hemiselulosa : Hemiselulosa yang dikonsumsi Hemiselulosa dalam feses

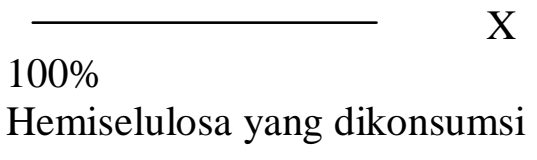


2. Kecernaan Selulosa :

Selulosa yang dikonsumsi -

Selulosa dalam feses

$100 \%$

Selulosa yang dikonsumsi.

Data yang diperoleh dianalisis sidik ragam yang sesuai dengan RAL.

Untuk mengetahui perbedaan antar perlakuan dilakukan uji beda nyata jujur (BNJ).

\section{Tatalaksana Penelitian}

Penelitian berlangsung dalam 3 tahapan, yaitu :

1. Tahap pendahuluan

Sebelum dilaksanakan

penelitian, ternak diberikan kesempatan untuk beradaptasi dengan pakan perlakuan. Adaptasi pakan dilakukan selama 2 minggu. Adaptasi dilakukan dengan tujuan untuk membiasakan ternak mengkonsumsi pakan perlakuan. Pada masa adaptasi, ternak diberi obat cacing untuk mencegah pengaruh cacing dan parasit. Setelah masa adaptasi, dilakukan pengambilan data konsumsi ternak selama enam hari. Pakan diberikan secara ad libitum dan air minum disediakan setiap saat. Konsumsi ternak dihitung dari kemampuan ternak mengkonsumsi pakan perlakuan yang dihitung berdasarkan konsumsi bahan kering.

2. Tahap pra-koleksi

Dua hari sebelum pengambilan data koleksi, dilakukan pembatasan pemberian pakan sebanyak $85 \%$ dari rataan konsumsi pakan pada tahap pendahuluan. Pembatasan pakan dilakukan agar pakan yang diberikan dapat dikonsumsi secara keseluruhan dan tidak tersisa.

\section{Tahap koleksi}

Pada tahap ini, pakan tetap diberikan sebanyak $85 \%$. Pada tahap ini dilakukan juga pengumpulan feses yang dilakukan mulai pukul 08.00 WITA sampai dengan keesokan harinya pada jam yang sama. Pengumpulan feses dilakukan selama tiga hari.

\section{Pengambilan Sampel}

Pengambilan sampel pakan dan feses dilakukan selama 3 hari. Pengambilan sampel pakan sebanyak 200 gr rumput benggala dan 50 gr konsentrat. Pengambilan sampel feses sebanyak $30 \%$ dari total feses pada setiap ternak per hari. 


\section{Analisa Sampel}

Analisa sampel menggunakan metode analisis serat oleh Van Soest dan Robertson (1985) yaitu untuk analisa NDF (Neutral Detergent Fiber), sampel dilarutkan menggunakan NDS (Neutral Detergent Solution). Berat sampel yang tersisa adalah berat dari NDF. Untuk analisa ADF (Acid Detergent Fiber), sampel dilarutkan menggunakan ADS (Acid Detergent Solution). Berat sampel yang tersisa adalah berat dari ADF. Hemiselulosa diperoleh dari selisih antara NDF dan ADF. Selulosa diperoleh dari residu ADF yang dilarutkan dengan $\mathrm{H}_{2} \mathrm{SO}_{4}$ $72 \%$. Berat sampel yang hilang adalah berat dari selulosa.

\section{HASIL DAN PEMBAHASAN}

Data hasil penelitian pengaruh penggunaan konsentrat dalam pakan berbasis rumput benggala terhadap kecernaan hemiselulosa dan selulosa pada kambing lokal dapat dilihat dalam tabel 4.

\section{Kecernaan Hemiselulosa}

Rataan nilai kecernaan hemiselulosa berkisar antara 66.38 $77.95 \%$ (Tabel 4). Hasil analisis keragaman menunjukkan bahwa perlakuan memberikan pengaruh yang berbeda nyata $(\mathrm{P}<0.05)$ terhadap nilai kecernaan hemiselulosa pada kambing lokal. Hasil uji lanjut BNJ menunjukkan bahwa kecernaan hemiselulosa R1 (66.38 \%) tidak berbeda nyata dengan R2 (73.42 \%), dan berbeda sangat nyata dengan R3 (77.67\%) dan $\mathrm{R} 4$

Tabel 4. Pengaruh penggunaan konsentrat dalam pakan berbasis rumput benggala terhadap kecernaan hemiselulosa dan selulosa pada kambing lokal.

\begin{tabular}{lcccc}
\hline & \multicolumn{4}{c}{ Perlakuan } \\
\cline { 2 - 5 } & $\mathrm{R} 1$ & $\mathrm{R} 2$ & $\mathrm{R} 3$ & $\mathrm{R} 4$ \\
\hline Hemiselulosa (\%) & $66.38^{\mathrm{a}} \pm 5.70$ & $73.42^{\mathrm{ab}} \pm 5.33$ & $77.67^{\mathrm{b}} \pm 1.97$ & $77.95^{\mathrm{b}} \pm 0.90$ \\
Selulosa (\%) & $65.50^{\mathrm{a}} \pm 0.51$ & $66.99^{\mathrm{ab}} \pm 2.28$ & $70.23^{\mathrm{b}} \pm 1.42$ & $70.03^{\mathrm{b}} \pm 1.42$ \\
\hline
\end{tabular}

Ket. : Nilai pada baris yang sama dengan superskrip yang berbeda menunjukkan pengaruh yang berbeda nyata $(\mathrm{P}<0.05)$. 


\section{Kecernaan Hemiselulosa}

Rataan nilai kecernaan

hemiselulosa berkisar antara 66.38 $77.95 \%$ (Tabel 4). Hasil analisis keragaman menunjukkan bahwa perlakuan memberikan pengaruh yang berbeda nyata $(\mathrm{P}<0.05)$ terhadap nilai kecernaan hemiselulosa pada kambing lokal. Hasil uji lanjut BNJ menunjukkan bahwa kecernaan hemiselulosa R1 (66.38 \%) tidak berbeda nyata dengan R2 (73.42 \%), dan berbeda sangat nyata dengan R3 (77.67 \%) dan R4 (77.95\%); sedangkan R2 tidak berbeda nyata dengan R1, R3, dan R4. Adanya peningkatan kandungan protein dalam pakan diduga menjadi faktor utama meningkatnya kecernaan hemiselulosa dengan bertambahnya konsentrat dimana di dalam rumen, protein didegradasi menjadi NH3 yang kemudian diabsorbsi menjadi $\mathrm{NH}_{4} \mathrm{OH}$. $\mathrm{NH}_{4} \mathrm{OH}$ ini bersifat basa sehingga $\mathrm{pH}$ rumen tetap normal. Hal ini didukung oleh pendapat Owen dan Goetsch (1988) yang menyatakan bahwa pada $\mathrm{pH} 5,5-6,2$ aktivitas bakteri selulolitik dan hemiselulolitik akan terhambat dan meningkatkan aktivitas bakteri amilolitik sehingga kecernaan serat menurun. Hal ini terjadi pada ternak yang mendapat suplementasi konsentrat yang mengandung karbohidrat non struktural yang tinggi; sebaliknya pada $\mathrm{pH} 6,2-7,0$ aktivitas bakteri selulolitik dan hemiselulolitik akan meningkat dan lebih dominan dibanding aktivitas bakteri amilolitik sehingga kecernaan serat meningkat. Sebaliknya, pada $\mathrm{pH} 6,2-7,0$ aktivitas bakteri selulolitik dan hemiselulolitik akan meningkat dan lebih dominan dibanding aktivitas bakteri amilolitik sehingga kecernaan serat meningkat.

\section{Kecernaan Selulosa}

Rataan kecernaan selulosa berkisar antara $65.50-70.23 \%$ (Tabel 4). Hasil analisis keragaman menunjukkan bahwa perlakuan memberikan pengaruh yang berbeda nyata $(\mathrm{P}<0.05)$ terhadap nilai kecernaan selulosa. Hasil uji lanjut BNJ menunjukkan bahwa kecernaan selulosa pada R1 $(65.60 \%)$ tidak berbeda nyata dengan perlakuan R2 (66.99 \%), serta nyata lebih rendah dibanding R3 (70.23\%) dan R4 (70.03 \%); sedangkan antara R2, R3, dan R4 tidak berbeda nyata. Rendahnya nilai kecernaan selulosa pada R1 disebabkan karena kandungan protein perlakuan R1 (13.00 \%) lebih rendah dibanding perlakuan R3 (16.68 \%). Hal ini didukung oleh pendapat McDonald dkk. (1995) bahwa apabila kandungan protein dalam pakan rendah, maka konsentrasi amonia rumen akan rendah sehingga pertumbuhan mikroba rumen menjadi lambat dan proses degradasi karbohidrat terhambat. Terhambatnya degradasi 
karbohidrat mempengaruhi degradasi selulosa yang tergolong polisakarida.

Nilai kecernaan selulosa lebih rendah dibanding hemiselulosa. Hal ini diduga karena adanya peranan bakteri Butyrifibrio fibrisolvens yang populasinya meningkat bila proporsi konsentrat dalam pakan meningkat. Perubahan populasi dari bakteri ini di dalam rumen juga diikuti dengan perubahan tingkat kecernaan hemiselulosa karena bakteri ini mempunyai peranan yang cenderung lebih aktif pada hidrolisis hemiselulosa dibandingkan hidrolisis selulosa (Varel dan Dehority, 1989).

\section{KESIMPULAN}

Berdasarkan hasil penelitian dapat disimpulkan bahwa penggunaan konsentrat dalam pakan berbasis rumput benggala dapat mencapai $75 \%$, tetapi yang terbaik adalah pada penggunaan $25 \%$ konsentrat.

\section{DAFTAR PUSTAKA}

Hartadi, H., S. Reksohadiprodjo, S. Lebdosukojo, A. D. Tillman, L. C Kearl, L. E Harris. 1980. Tables of feed composition for Indonesia. International Feedstuffs Institute Utah Agricultural Experiment
Station, Utah State University Logan, Utah

Katipana, W. G. F., J. I. Manafe, dan L. Rusnawati. 1994. Diktat Kuliah Pengetahuan Bahan Makanan Ternak. Universitas Nusa Cendana. Kupang.

McDonald, P., R. A. Edwards, and J. F. D. Greenhalgh. 1995. Animal Nutrition. Third Edition. Longman, London, and New York.

Owen, F. N., A. L Goetsch. 1988. Ruminal fermentation in : D. C. Church (ed), the ruminant animal digestive phisiology and nutrition. Prentice Hall. Engwood Cliffs, New Jersey. P. (pp. $145-171$ )

Siregar, S. B. 1994. Pakan Ternak Ruminansia. Penebar Swadaya. Jakarta.

Steel RGD dan JH Torrie. 1993. Prinsip dan Prosedur Statistiks. Gramedia Pustaka Utama, Jakarta.

Tillman, A. D., H. Hartadi. S. Reksohadiprojo, S. Prawirokusumo dan S.

Lebdosoekodjo, 1989. Ilmu Makanan Ternak Dasar. Universitas Gadjah Mada. Jogjakarta 
Van Soest, J. P dan J. B. Robertson. 1985. Analysis of forages and fibrous foods. A laboratory manual for animal science 613.

Varrel, V.H. dan Burk A. Dehority. 1989. Ruminal cellulolytic bacteria and protozoa from bison, cattle bisson hybrids, and cattle fed three alfalfa - coin diets. Applied and Environmental Microbiology. Vol. 55 No. 1 